JINOTEP Vol 8 (3) (2021): 247-257

DOI: $10.17977 / \mathrm{um} 031 \mathrm{v} 8 \mathrm{i} 32021 \mathrm{p} 247$

JINOTEP (Jurnal Inovasi Teknologi Pembelajaran)

Kajian dan Riset Dalam Teknologi Pembelajaran

http://journal2.um.ac.id/index.php/jinotep/index

\title{
PENGEMBANGAN MEDIA 3D EXPLODED VIEW PADA ASYNCHRONOUS LEARNING
}

\author{
Muhammad Ihwanudin, Lutfi Nuril Anwar, Sumarli, Syarif Suhartadi \\ Pendidikan Teknik Otomotif Universitas Negeri Malang - Kota Malang
}

\section{Article History}

Received: 12-07-2021

Accepted: 13-09-2021

Published: 01-11-2021

\section{Keywords}

Learning media; $3 D$

Exploded View;

Asynchronous learning

\begin{abstract}
Abstrak
Tujuan inovasi media pembelajaran pada penelitian ini mewujudkan pengembangan media $3 D$ Exploded View yang dapat dimanfaatkan sebagai media pembelajaran mahasiswa pada mata kuliah praktikum sistem kontrol sasis. Platform peraga secara virtual ditargetkan mampu memberikan pengalaman belajar yang semakin kompleks melalui asynchronous learning yang saat ini telah berkembang pesat karena pergeseran paradigma belajar. Penelitian ini merupakan penelitian pengembangan dengan menerapkan model ADDIE. Media telah divalidasi secara konten dan konstruk dengan hasil layak dan valid digunakan. Hasil penelitian menunjukan penerapan media $3 D$ Exploded View pada kelas praktikum memberikan peningkatan signifikan pengalaman belajar, motivasi belajar, dan prestasi kognitif mahasiswa. Berdasarkan hasil analisis efektifitas dan kebermanfaatan disimpulkan media dinilai layak dan cocok diterapkan terhadap pembelajaran praktik pada universitas.
\end{abstract}

Corresponding author:

Muhammad Ihwanudin

Adress: J1. Tebo Tengah 114C Bandulan, Sukun Malang 65146

Instansi: Universitas Negeri Malang,

E-mail: m.ihwanudin.ft@um.ac.id
2021 Universitas Negeri Malang

p-ISSN 2406-8780

e-ISSN 2654-7953

\begin{abstract}
The purpose of the learning media innovation in this research is to realize the development of $3 D$ Exploded View media that can be used as a student learning media in the chassis control system practice class. The virtual learning platform is targeted to be able to provide increasingly complex learning experiences through asynchronous learning, which is currently growing rapidly due to a shift in the arning paradigm. This research is a development research by applying the ADDIE . The media has been validated in terms of content and constructs with proper media in the practicum class provided a significant increase in learning experience, and suitable to be applied to practical learning at universities. of effectiveness and usefulness, it is concluded that the media is considered feasible

Abstract
\end{abstract}




\section{PENDAHULUAN}

Pengembangan serta inovasi teknologi berubah secara dinamis dengan sangat pesat, diikuti dengan peningkatan ragam kebutuhan. Perkembangan dan inovasi tersebut diwujudkan melalui berbagai implementasi pada bidang industri, perdagangan, sistem komunikasi, transportasi serta pendidikan. Ciri teknologi tinggi yang dikembangkan antara lain adalah terwujudnya kesetimbangan antara segi material atau bahan sebuah teknologi terhadap tuntutan manusia ditandai dengan perubahan pola dan proses kehidupan yang memiliki sifat dinamis. Semakin kompleksnya tata kelola ekonomi di berbagai negara tentunya memberikan tantangan baru khususnya pada bidang ekonomi. Pola ekonomi telah bergeser dari model ekonomi nasional menuju ekonomi global. Keadaan dunia yang semakin penuh dengan resiko serta memiliki derajat ketidakpastian yang tinggi memicu manusia untuk dapat memperkirakan masa depan, ditambah lagi ketergantungan terhadap sumber daya yang tak dapat diperbarui atau unrenewable resources dapat dijadikan pelajaran betapa dibutuhkannya pendekatan jangka panjang berbasis teknologi. Istilah lain dapat dinyatakan pendidikan memiliki kontribusi yang besar bagi pengembangan teknologi.

Perubahan paradigma belajar dan strategi pembelajaran pada tingkat universitas era teknologi sangatlah terasa. Berbagai upaya yang dilakukan pendidikan tinggi khususnya Universitas Negeri Malang dalam kasus ini sudah tampak jelas, contoh nyata adalah dilaksanakannya perubahan kurikulum hingga proses teknis pembelajaran di setiap jurusan dan program studi dilakukan dengan efisien baik dalam bentuk sinkron maupun asinkron activity. Berbagai upaya pengembangan proses pembelajaran tersebut dikembangkan dengan tujuan utama adanya inovasi belajar yang mengoptimalkan proses belajar, sehingga mampu membentuk sikap mandiri, kreatif, dan produktif mahasiswa. Upaya inovasi belajar diharapkan mampu mendukung perkembangan potensi akademik mahasiswa secara holistik, baik potensi kognitif, skills maupun afektif. Selain itu juga diharapkan mampu menumbuhkan potensi mahasiswa sebagai bentuk potensi pendidikan sebagai kecakapan hidup (Anwar, 2012).

Secara umum asynchronous learning didefinisikan sebagai bentuk pendidikan maupun strategi dalam pembelajaran yang memiliki ciri pembelajaran tidak terjadi pada tempat dan waktu bersamaan. Asynchronous learning memiliki cara atau instruksi belajar yang sangat beragam, tanpa mengurangi esensi pesan dan pengalaman belajar yang diperoleh. Pembelajaran ini juga sangat kental dengan nuansa digital dan metode belajar berbasis online yang dapat melibatkan media berupa video tutorial, modul dan buku elektronik maupun pemanfaatan media atau platform model lain. Kontribusi positif asynchronous learning sangat bergantung terhadap pemanfaatan media dan akurasi sumber belajar yang disiapkan. Ditinjau dari beragam karakteristik tersebut, asynchronous learning merupakan bentuk cara belajar yang didesain secara sistematik untuk dapat dimanfaatkan secara optimal.

Beberapa temuan lapangan melalui observasi menunjukkan bahwa kontribusi berwujud inovasi teknologi pembelajaran memiliki sumbangsih yang nyata bagi peningkatan kualitas pembelajaran khususnya mata kuliah praktikum. Hal ini juga didukung oleh konsep belajar dan pembelajaran yang menyatakan penggunaan media belajar yang komprehensif dan sesuai memiliki peran penting guna meningkatkan pengalaman belajar dan hasil belajar. Program studi teknik otomotif pada semester berjalan tahun akademik 2020/2021 mata kuliah sistem kontrol sasis ditemukan indikasi gangguan proses pembelajaran serta indikasi kurangnya pemanfaatan media pada proses pembelajaran praktik. Kemudian muncul juga kendala lain misalnya kurangnya motivasi belajar mahasiswa praktikan dalam mengikuti proses perkuliahan di laboratorium sistem sasis dan pemindah tenaga.

Secara umum piranti dan kelengkapan laboratorium telah dinilai sesuai untuk digunakan dan dimanfaatkan oleh mahasiswa. Namun hal tersebut tidak serta merta mampu dimanfaatkan secara efisien oleh mahasiswa melalui belajar mandiri di laboratorium. Dari analisis kelengkapan alat dan bahan praktikum di laboratorium Teknik Mesin dapat diklasifikasi menjadi beberapa sub bagian misalnya laboratorium bagian sistem pemindah tenaga bagian suspensi dan absorpsi, dan bagian sistem rem. Semua bagian sub laboratorium tersebut dimanfaatkan secara optimal sebagai penunjang utama keterlaksanaan proses pembelajaran di laboratorium teknik mesin. 
Pada kasus ini pengembangan media yang dilakukan berfokus pada pembahasan bagian sistem rem kendaraan. Pembelajaran praktik yang diterapkan diharapkan mampu memupuk kreativitas, dan menghasilkan learning outcome, mencetak lulusan menjadi insan yang mampu berkompetisi secara profesional di berbagai bidang kehidupan dan sosial masyarakat. Jika dikaitkan lulusan tingkat sarjana terhadap karakteristik learning outcome tersebut, sarjana didefinisikan harus memenuhi standar level keenam menurut Peraturan Presiden RI Nomor 8 Tahun 2012 tentang Kerangka Kualifikasi Nasional Indonesia (KKNI). Terlebih lagi pada situasi masa pandemic perubahan pembelajaran sangat kental terasa, tidak hanya perubahan aktivitas keseharian untuk mengutamakan pola hidup aman dan sehat, namun juga turut berdampak langsung terhadap strategi pembelajaran di tingkat universitas. Situasi ini tentunya menjadi revolusi bagi stakeholder universitas termasuk dosen untuk mengubah aktivitas mengajarnya. Berdasarkan edaran universitas yang mengumumkan pembelajaran dilaksanakan secara daring memberikan dampak pada konten sajian mata kuliah. Tentunya tetap mengacu terhadap koridor kurikulum setiap jenjang dan program studi.

Aktivitas belajar secara ideal harus mencakup seluruh aspek, meliputi jasmani dan rohani manusia. Supaya pada akhirnya dapat mengakselerasi perubahan tingkah laku manusia secara tepat. Ditandai dengan perubahan berbagai aspek baik kognitif, afektif dan psikomotorik. Atau secara lebih sederhana diartikan bahwa belajar merupakan aktivitas yang mampu memberikan nilai tambah dan dapat diukur secara konkret serta dapat dipertanggungjawabkan melalui kaidah benar dan akurat (Suhana, 2014).

Urgensi penelitian ini didasarkan dari hasil kegiatan observasi dan monitoring evaluasi aktivitas pembelajaran daring sinkron dan asinkron di tingkat prodi oleh tim pengembang dan data dari Penjamin Mutu (SPM) menunjukan hasil berikut: (1) pelaksanaan pembelajaran daring mata kuliah teoritik berjalan baik dan cukup efektif dengan skor rerata $76-82 \%$; sedangkan (2) pelaksanaan pembelajaran daring mata kuliah praktikum berjalan kurang baik dan dinilai tidak efektif dengan skor rerata 51-63\%. Kasus ini mungkin juga dialami oleh prodi lain yang memiliki aktivitas pembelajaran praktikum yang setipe. Masalah pembelajarn yang semakin rumit tersebut membutuhkan tindakan yang tepat untuk memberikan kontribusi perbaikan yang positif (Ipate, Ilie, \& C, 2020).

Tentunya kasus ini perlu diambil tindakan atau upaya perbaikan yang tepat. mengacu terhadap urgensi masalah yang dialami, peneliti gerak untuk menawarkan solusi dalam wujud skema penelitian inovasi belajar. melalui penelitian ini peneliti berharap mampu menyelesaikan masalah pembelajaran yang dialami. sehingga peneliti mengangkat tema pengembangan media belajar visual $3 D$ Exploded View.

Media 3D Exploded View merupakan media berbasis augmented reality (AR) yang tentunya melibatkan piranti komputer dan gadget untuk pembuatan dan pemanfaatannya. Tidak jauh berbeda dengan model dasar pengembangan augmented reality namun memiliki tingkat konstruksi gambar dasar yang lebih tinggi. Hal tersebut disebabkan karena komponen gambar yang dapat ditampilkan memiliki jumlah yang lebih banyak dan beragam, serta harus disusun secara berurutan sesuai standar operasi prosedur pada sebuah konstruksi mesin maupun peralatan berbasis visual (Karisman, Wulandari, \& Adipraja, 2019).

Tujuan utama penelitian ini adalah meningkatkan pengalaman belajar mahasiswa pada kelas praktikum sistem kontrol sasis. meningkatkan efektivitas proses pembelajaran perkuliahan. Meningkatkan hasil belajar mata kuliah praktikum sistem kontrol sasis. melalui pengembangan media belajar yang interaktif menarik dan fleksibel diharapkan menyelesaikan masalah dalam pembelajaran. Orientasi akhir proses tersebut adalah learning outcome. Hal ini berhubungan dengan lulusan perguruan tinggi yang telah dicantumkan pada kurikulum masingmasing program studi di UM.

Secara ideal memang perlu adanya inovasi belajar berkelanjutan khususnya dari dosen pengajar di tingkat program studi untuk peningkatan kualitas pembelajaran. Secara general inovasi diartikan sebagai ide, praktik, maupun sebuah objek baru yang nilai manfaatnya positif sekaligus berkontribusi secara parsial maupun absolut terhadap individu atau objek sasaran (Nisaun, Subiyanto, \& Murnomo, 2020). Inovasi pembelajaran dalam penelitian ini dengan menerapkan media $3 D$ Exploded View pada mata kuliah sistem kontrol sasis dan pemindah tenaga. Melalui pengembangan ini diharapkan mampu menggabungkan teknologi dengan segala 
250 JINOTEP (Jurnal Inovasi dan Teknologi Pembelajaran) Kajian dan Riset dalam Teknologi Pembelajaran Vol.8, No.3, November 2021, Hal. 247-257

keunggulannya untuk diterapkan pada pembelajaran konvensional atau secara umum media exploded view dinilai mampu untuk mengakomodasi kebutuhan tersebut dengan cara memberikan peningkatan interaksi antara pesan visual berupa gambar, diagram dan grafik kepada manusia (Wilmot, Agrawala, Curless, \& Salesin, 2018).

Keunggulan media exploded ini adalah dapat diperuntukan pada berbagai peragaan, percontohan operasi kerja, promosi dan latihan ataupun bentuk visual lainnya (Widayaningsih, 2020). Pada bidang teknik, model view exploded juga diterapkan pada desain dan manufaktur misalnya diterapkan pada assembly dan disassembly sebuah produksi mesin dan robot. Pemodelan exploded sangat membantu untuk memproyeksikan desain sumbu tiga dimensi yang lebih akurat (Costa, et al., 2018). Dari berbagai keunggulan tersebut dinilai tepat jika dimanfaatkan khususnya untuk pembelajaran mata kuliah sistem kontrol sasis dan pemindah tenaga prodi pendidikan teknik otomotif yang dilaksanakan di laboratorium otomotif jurusan teknik mesin FT-UM serta diharapkan mampu memberikan kontribusi pengalaman belajar mahasiswa yang menarik, unik, komunikatif dan interaktif sehingga pada akhirnya mampu meningkatkan kebermaknaan kegiatan belajar.

\section{METODE}

Rancangan produk pada penelitian pengembangan $3 D$ Exploded View sebagai inovasi belajar yang diterapkan pada Mata Kuliah Sistem Kontrol Sasis dan Pemindah Tenaga PPTOUM6039 di program studi S1 Pendidikan Teknik Otomotif dengan menggunakan rancangan penelitian pengembangan. Metode pengembangan tersebut dinilai cocok untuk digunakan pada penelitian karena mampu mengadopsi kebutuhan sesuai tahap penelitian. Mengaktualkan serta mewujudkan sebuah produk yang dapat diukur sesuai indikator dan tujuan penelitian (Choy, $\mathrm{Xu}$, Gwak, Chen, \& Savarese, 2016).

Pengembangan $3 D$ Exploded View mengacu terhadap pemanfaatan media belajar modern dan dihubungkan dengan teknologi multimedia dan informasi yang bertujuan menghasilkan kecepatan pemahaman konseptual dan efisiensi waktu dalam sebuah pembelajaran yang telah direncanakan (Tymrak, Kreiger, \& J.M.Pearce, 2014). Penelitian ini mengadopsi pengembangan model instruksional ADDIE yang mencakup lima tahap meliputi tahap analisis (analysis), tahap desain (design), tahap pengembangan (development), tahap implementasi (implementation) dan tahap evaluasi (evaluating). Pelaksanaan penelitian ini mempertimbangkan beberapa poin sebagai koridor atau diartikan faktor kontrol penelitian misalnya (1) waktu pengembangan media, (2) implementasi media kepada lingkungan tertentu, (3) spesifikasi media berfokus pada kompetensi sistem rem.

Tahapan penelitian pengembangan inovasi media pembelajaran $3 D$ Exploded View dengan mengadopsi model instruksional ADDIE memiliki urutan yang baku dan tidak dapat dilakukan jika bertentangan terhadap konsep pengembangan tersebut, secara spesifik dapat dirincikan melalui tahapan berikut:

\section{Tahap Analisis}

Tahap analisis pada bagian ini memiliki beberapa fokus, antara lain diklasifikasi sebagai berikut,

\section{a. Analisis situasi pembelajaran}

Observasi peneliti pada semester genap tahun akademik 2019/2020 ditemukan bahwa sebagian dari mahasiswa belum sepenuhnya mampu mencapai standar capaian lulusan yang tertuang pada kurikulum mata kuliah secara merata. Hal ini mengindikasikan bahwa terjadi kendala pada proses belajar mahasiswa khususnya pada pemahaman konseptual materi atau topik yang dipelajari.

\section{b. Analisis kurikulum}

Analisis ini menitikberatkan pada kajian relevansi sajian dan konten mata kuliah ditinjau dari indikator dan sajian materi pada RPS mata kuliah terhadap tujuan pembelajaran atau CPL mata kuliah. Kesesuaian isi kurikulum program studi telah dinilai layak karena telah melalui tahapan pengembangan dan validasi oleh tim pengambang kurikulum tingkat program studi maupun universitas.

\section{c. Analisis media}

Analisis ini dikhususkan untuk mengkaji kompetensi dan materi yang dipilih sebagai konten pembuatan media. materi sistem rem menjadi pilihan utama karena dinilai paling vital untuk dikuasai konsep dan kinerjanya terlebih dahulu dibanding sajian lainnya. Sedangkan sub kompetensi lainnya akan dilakukan tindakan setelah hasil evaluasi dan simpulan didapatkan.

\section{Tahap Desain}

Tahap desain merupakan fase rancangan dasar media dengan cara menerapkan konsep 
yang telah dikaji dan melawati proses training dan sharing technology pihak industri pemegang merek otomotif suzuki (PT SIS) di Jakarta. Berdasarkan hasil pelatihan tersebut, kemudian dilakukan breakdown materi menjadi turunan sub materi yang disesuaikan terhadap kurikulum program studi, pada akhirnya disajikan pada materi mata kuliah berbentuk paket materi pembelajaran. Paket materi pembelajaran yang sudah lengkap dan sesuai tersebut, sangat relevan jika disajikan dalam sebuah aplikasi berbasis android berbentuk media mobile learning (Weng, Wanga, T.Senthil, \& Wu, 2016). Menyiapkan rancangan tampilan media, melakukan instalasi software yang akan digunakan, pengumpulan bahan dan materi yang sesuai dengan karakteristik belajar mahasiswa FT-UM.

\section{Tahap Pengembangan}

Tahap pengembangan merupakan proses mengembangkan $3 D$ Exploded View berbasis AR menjadi produk tahap awal.

\section{a. Integrasi gambar media pembelajaran}

Langkah pertama dalam pengembangan adalah pembuatan model gambar 3D, peneliti menggunakan Autodesk inventor 2018 (.stl). Kemudian hasil model 3D diimport ke dalam software Blender untuk diberi warna dan dikonversikan menjadi format (.fbx). Setelah itu model akhir diolah menggunakan software Unity untuk pembuatan animasi dan user interface. Kemudian aplikasi yang sudah jadi di build menjadi file (.apk) agar bisa digunakan di sistem android.

\section{b. Validasi ahli materi dan ahli media}

Proses validasi pada penelitian ini dilakukan kepada ahli media dan ahli materi yang telah ditentukan. Melalui skema tersebut proses putusan atau simpulan validator ahli menjadi masukan utama pada proses perbaikan media yang dibuat. Catatan validator ahli tersebut menunjukan kekurangan keunggulan serta saran yang konstruktif. Standar tingkat kesulitan aitem materi juga telah disesuaikan terhadap sajian kurikulum program studi sehingga sesuai target hasil belajar (Azwar, 2014). Catatan penting validator ahli tersebut diterjemahkan menjadi poin-poin perbaikan produk dari aspek materi dan konstruksi media. Validasi ahli merupakan kunci utama dalam pengembangan sebuah produk melalui penelitian. Baik dan buruknya sebuah produk umumnya juga berbanding lurus terhadap independensi proses validasi. Sehingga aspek ini memiliki peran kunci dalam tahapan pengembangan sebuah produk (Chen, Ma, Wan, Li, \& Xia, 2017).

Kriteria penilaian validasi ahli materi dan media berdasarkan beberapa inti penting berkorelasi terhadap konsep. Framework validasi ahli materi meliputi: (1) kevalidan materi terhadap target kompetensi lulusan, (2) Kesesuaian materi terhadap kurikulum, (3) kesesuaian indikator capaian belajar terhadap aspek penilaian, (4) kesesuaian terhadap tujuan belajar. Selanjutnya framework validasi media meliputi (1) media dapat dimanfaatkan untuk mencapai tujuan belajar. (2) media menyampaikan materi secara jelas. (3) media mengaitkan belajar mahasiswa pada target kompetensi, (4) media dapat dioperasikan secara mudah oleh mahasiswa, (5) media mampu meningkatkan pemahaman mahasiswa secara efektif. (6) media membangun koneksi dan sinergi antara sumber belajar lain yang saling suportif.

\section{Tahap Implementasi}

Pada tahap implementasi ini produk diuji cobakan terhadap mahasiswa pada mata kuliah kontrol sasis dan pemindah tenaga PPTOUM6039 di prodi S1 pendidikan Teknik Otomotif. Pada tahapan ini dilakukan pengambilan data lapangan melalui lembar instrumen untuk kebutuhan data pengukuran sekaligus mengetahui respon maupun umpan balik 31 mahasiswa mengenai pengalaman belajar menggunakan media pembelajaran berwujud aplikasi $3 D$ exploded view untuk mata kuliah kontrol sasis dan pemindah tenaga. Tahap implementasi media juga sebagai ajang program studi untuk unjuk karya hasil penelitian di setiap periode. Tindakan tersebut sebagai wujud upaya promosi produk inovasi pembelajaran yang efektif (Pangestu, Fitri, \& Fauziah, 2020).

\section{Tahap Evaluasi}

Pada tahap ini dilakukan proses evaluasi dari data hasil uji coba terbatas desain $3 D$ Exploded View. Hasil tersebut kemudian dimaknai sekaligus ditentukan tindakan sesuai dengan hasil feedback. Produk disempurnakan berdasarkan hasil analisis tersebut mengacu terhadap standar kelayakan media belajar. Pada tahap ini juga telah dilakukan analisis dengan melibatkan aturan yang baku, baik secara taktik dan konsep. Kemudian pada tahap selanjutnya dapat diuji kembali media yang telah direvisi tersebut untuk dilakukan uji coba lapangan kedua yang lebih luas.

Pada aspek lainnya, untuk mengukur capaian prestasi kognitif mahasiswa praktikan, 


\begin{tabular}{ccc}
\hline \multicolumn{3}{c}{ Tabel 1. Desain Uji } \\
\hline Pre-Test & Perlakuan & Post-Test \\
\hline$X_{1}$ & $\mathrm{O}$ & $\mathrm{X}_{2}$ \\
\hline
\end{tabular}

$\overline{\text { dilakukan tes teori dengan tujuan meningkatkan }}$ motivasi pada diri mahasiswa untuk lebih giat dalam belajar. Konsep pengukuran prestasi kognitif sebagai motivator dalam belajar telah dikemukakan di beberapa konsep teori belajar. Konsep ini pada dasarnya sederhana, namun cukup efektif untuk diaktualisasikan. Tujuannya adalah dapat dimunculkan feedback pada akhir sesi proses belajar (Azwar, 2014). Menimbang pentingnya tahap asesmen pada sebuah pembelajaran, implementasi media juga perlu adanya tahap pengukuran maupun penilaian. Penilaian yang dimaksud tentunya adalah penilaian hasil belajar aspek kognitif (Basuki I, 2014).

Hasil implementasi produk inovasi belajar dalam bentuk media $3 D$ Exploded View ini ditargetkan kepada 31 mahasiswa kelas praktik mata kuliah sistem kontrol sasis. Dilakukan proses analisis data dengan melibatkan teknik uji beda 2 sisi secara berpasangan paired sample $t$ test atau dikenal dengan uji t desain pretestposttest.

\section{HASIL}

Hasil utama penelitian berupa produk media belajar yang telah dimanfaatkan pada mata kuliah program studi teknik otomotif. Melalui tahapan yang cukup panjang, media dikembngan dari sebuah konstruksi gambar 2 dimensi kemudian di extrude menjadi bentuk tiga dimensi. Dilakukan langkah pembuatan skala dan ukuran yang diadopsi dari manual book kendaraan. Input ukuran serta pembuatan bentuk dasar tersebut dilakukan dengan bantuan software autodesk inventor. Program tersebut memang cocok digunakan untuk pembuatan rancangan gambar khususnya untuk gambar di bidang teknik mesin. Karena memiliki fitur yang relevan dengan desain dan profil gambar pada bidang teknik dan implementasinya. Bentuk media yang dikembangkan berfokus terhadap sistem rem. diawali dari pembuatan desain disk brake, seperti ditunjukan pada Gambar. 1 desain awal komponen sistem rem.

Pada proses pembuatan gambar dasar ini peneliti telah menganalisis serta menentukan ukuran sekaligus menskalakan ukuran tersebut sesuai ukuran komponen aslinya. Tujuan penentuan skala tersebut adalah mengaktualkan gambar terhadap ukuran benda aslinya.

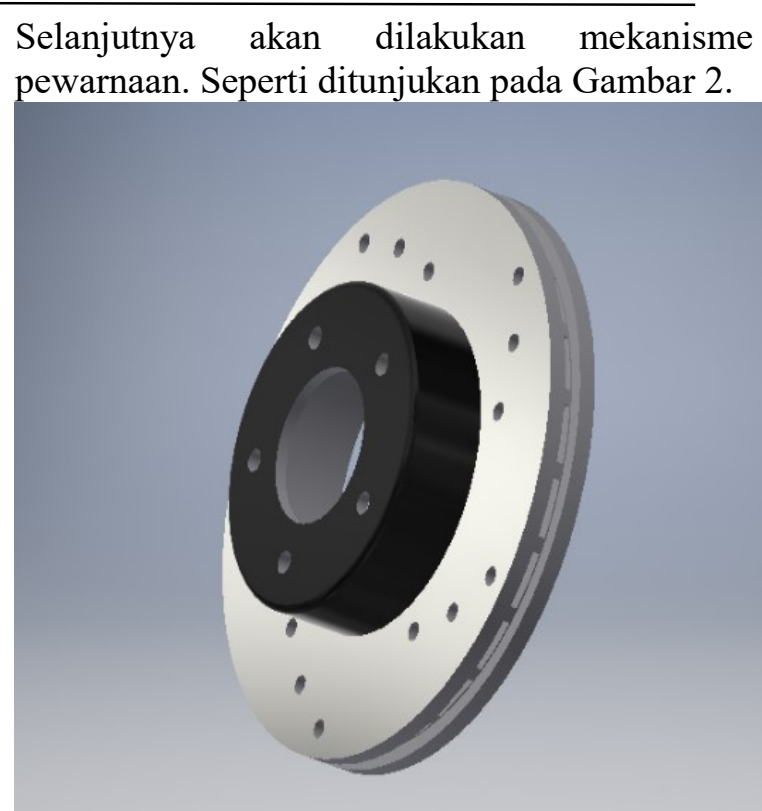

Gambar 1. Desain awal rem Sumber : Dokumen Peneliti

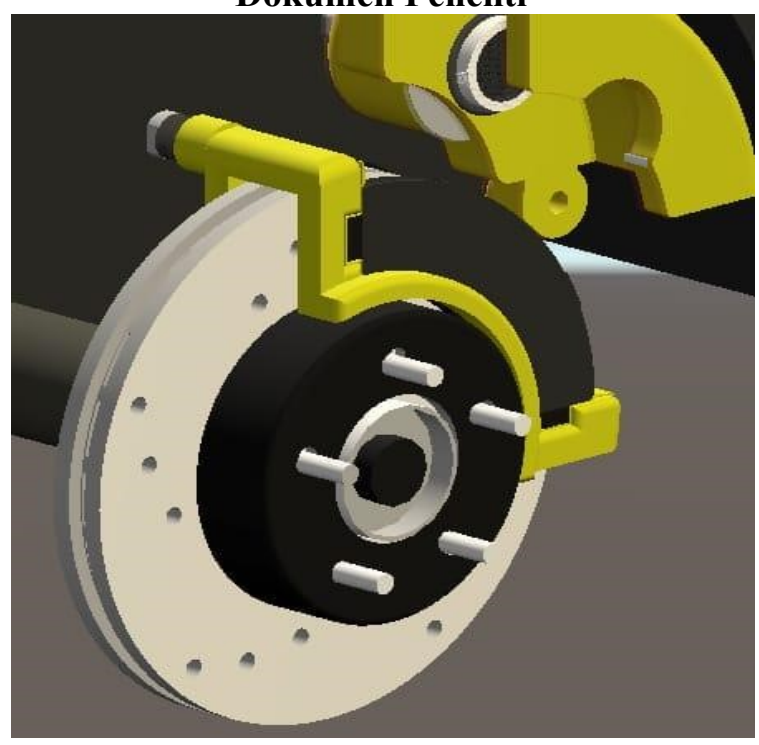

Gambar 2. Pengaturan Exploded dan

Pewarnaan Sumber : Dokumen Peneliti

Pada proses pengaturan dan pewarnaan ini telah disesuaikan sedemikian rupa supaya dapat ditampilkan pada platform android secara jelas. Model gambar tiga dimensi secara kompleks tersebut memiliki banyak ukuran komponen dimulai dari ukuran sub komponen bagian kecil sampai dengan bagian ukuran yang besar, sehingga harus diatur supaya tidak terhimpit, dengan kata lain, gambar tersebut telah diatur untuk tidak saling berhimpit antara komponen satu terhadap komponen lainnya.

Bagian gambar yang terpisah tersebut kemudian dikompilasi menjadi satu bagian yang utuh kemudian dimasukan pada sebuah platform android serta dilengkapi dengan display menu 


\section{AR BRAKE BD}

Aplikasi pembelajaran sistem rem

Model 3D

Materi

Petunjuk penggunaan

Tentang aplikasi

Keluar

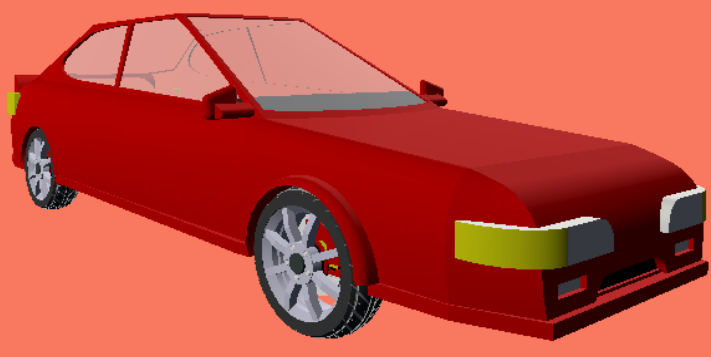

Versi 1.0

Gambar 3. Tampilan Media 3D Exploded View Sumber : Dokumen Peneliti

Tabel 2. Hasil Validasi Produk

\begin{tabular}{ccccc}
\hline No. & Aspek & Skor Rerata & Kriteria Kelayakan & Justifikasi \\
\hline 1 & Konten/ Materi & 0,87 & $0,67-1,00$ (Valid); & Valid \\
2 & Konstruksi media & 0,79 & $\leq 0,66$ (Tidak valid) & Valid \\
\hline
\end{tabular}

serta bagian input pilihan. Pada menu terdapat pilihan model 3D, materi, petunjuk penggunaan dan aplikasi pengembang. Tampilan media halaman utama disajikan pada Gambar 3.

Validasi ahli dilakukan untuk mengetahui kelayakan dan kesesuaian media pada aspek konten dan konstruksi. Secara kriteria uji coba instrumen penelitian, sebuah alat ukur dinyatakan valid jika memenuhi kriteria nilai 0,67-1,00 dan dinyatakan tidak valid jika menunjukan nilai kurang dari 0,66 . Hasil dari validator ahli media memberikan skor sebagaimana data pada Tabel 2.

Berdasar hasil analisis data implementasi produk media terhadap mahasiswa kelas praktik menunjukan interpretasi sebagai berikut, nilai rerata pretest sebesar 67 dengan standar deviasi sebesar 2,76. Nilai rerata posttest 78,8 dengan standar deviasi sebesar 4,3. Sehingga didapatkan skor sig. 2 tailed $0,00<0,05$ sehingga $\mathrm{H}_{0}$ ditolak yang maknanya terdapat perbedaan hasil nilai yang signifikan terhadap penggunaan media pada kelas praktikum sistem chasis. Pada aspek kebermaknaan belajar dari kuesioner yang didapatkan menunjukan hasil rerata skor sebesar 86,8 dengan makna sangat baik. Kemudian dari aspek motivasi belajar mahasiswa mendapatkan skor rerata 87,6 dengan makna sangat baik. Sedangkan pada aspek efektivitas menunjukan skor persentase keefektifan media sebesar $72 \%$ lebih efektif dari pembelajaran tanpa media. Secara umum produk media dapat dimanfaatkan dengan sangat baik dan berkontribusi positif bagi pembelajaran praktik.

\section{PEMBAHASAN}

Berangkat dari kondisi ideal bahwa tindakan implementasi teknologi tepat guna pada bidang pendidikan, tentunya harus memberikan dampak yang positif. Makna kontribusi tersebut misalnya meningkatkan efisiensi kerja yang berimbas terhadap pencapaian tujuan belajar. walaupun disisi lain tidak jarang percepatan implementasi teknologi juga memiliki efek negatif misalnya bergantinya sebuah teknologi konvensional, melonjaknya kebutuhan maupun konsumsi energi, pergeseran kebiasaan lama. Perkembangan paradigma masa kini pendidikan menempatkan mahasiswa sebagai agen pengembang teknologi pada ruang lingkup perguruan tinggi (Sonhadji, 2013).

Mahasiswa dan dosen merupakan unsur utama sebagai agen pengembang teknologi. perubahan ini semakin terlihat nyata misalnya berwujud kepedulian sosial bergeser menjadi kepedulian profesional dan vokasional. kebijakan kebebasan akademik secara yuridis dijamin perundangan nomor 12 tahun 2012 
254 JINOTEP (Jurnal Inovasi dan Teknologi Pembelajaran) Kajian dan Riset dalam Teknologi Pembelajaran Vol.8, No.3, November 2021, Hal. 247-257

tentang pendidikan tinggi pasal 9 ayat 1 menerangkan kebebasan akademik merupakan kebebasan civitas akademika dalam pendidikan tinggi guna mendalami dan mengembangkan ilmu pengetahuan dan teknologi secara bertanggung jawab dalam wujud pelaksanaan Tridharma. Hal ini pula mendorong mahasiswa untuk lebih kreatif, inovatif, logis, berorientasi masa depan dengan tetap mematuhi kaidah keilmuan.

Berbagai poin kebutuhan tersebut harus diadopsi dalam desain kurikulum yang ideal. pada desain kurikulum ideal minimal dapat ditandai dari dua dimensi utama yaitu dimensi horizontal dan vertikal. Dimensi horizontal memiliki fokus terhadap isi kurikulum misalnya berkaitan aspek proses pembelajaran kondisi tertentu. Sedangkan dimensi vertikal memiliki fokus penyusunan serta relevansi bahan sajian pada kurikulum berdasarkan tingkat kebutuhan dan tantangan lulusan. berdasarkan pada fokus pengajaran minimal ada ada 3 desain antara lain: (1) Subject Centered Design, merupakan desain kurikulum yang memiliki fokus pada aspek pengembangan bahan ajar; (2) Learner Centered Design, merupakan desain kurikulum yang memiliki fokus terhadap peranan siswa pada pembelajaran; (3) Problems Centered Design, merupakan desain kurikulum yang berorientasi terhadap masalah yang terjadi dalam lingkup masyarakat. Sebuah kurikulum dinyatakan ideal jika mampu mengadopsi dan menyelesaikan masalah yang ada pada berbagai kondisi yang dihadapi (Sukmadinata, 2013).

Kurikulum pada program studi S1 pendidikan teknik otomotif telah didesain sedemikian rupa untuk mampu menjawab kebutuhan lulusan yang relevan terhadap perkembangan teknologi. berdasarkan data observasi menunjukkan bahwa pembelajaran pada kelas praktik memiliki tingkat efektivitas sebesar $56 \%$ artinya proses pembelajaran dinilai belum optimal. sedangkan melalui pretest terhadap 31 mahasiswa menunjukkan hasil kemampuan kognitif mahasiswa rerata nilai sebesar 62,54. sedangkan dari hasil forum diskusi ditemukan beberapa poin yang menjadi hambatan pada proses pembelajaran perkuliahan praktik. Tentunya dari hasil observasi tersebut dapat diambil kesimpulan awal bahwa terjadi problem dalam pembelajaran.

Pembuatan media belajar $3 D$ exploded view menjadi pilihan sebagai upaya menyelesaikan masalah yang terjadi. Media exploded view pada teknisnya merupakan satu bagian dengan desain augmented reality (AR) namun terdapat bagian khusus yang dapat diunggulkan yaitu fungsi exploded yang unik (Tasrif, Mubai, Huda, \& Rukun, 2020). Media tersebut secara konseptual yang disebut dengan visualisasi model 3D merupakan bentuk objek yang melibatkan penggunaan sumbu atau sering disebut sebagai 3 aksis yaitu $\mathrm{x}, \mathrm{y}$ dan $\mathrm{z}$ untuk diposisikan pada suatu lokasi tertentu atau layout 3D, selanjutnya jika dihubungkan dengan beberapa bentuk objek secara geometris misalnya objek berbentuk segitiga, garis, bidang lengkung. Masing-masing poin tersebut memiliki nilai koordinat yang disebut dengan grid. Selanjutnya melalui cara menghubungkan titik tersebut menjadi bentuk bidang atau disebut dengan shape, maka permukaan dari suatu objek akan secara pelanpelan mulai tampak (Mayilyan, 2019).

Model 3D tersebut dapat dihasilkan dari berbagai cara mulai dari dapat dibuat dengan tangan atau menggambar secara manual, menggunakan formulasi algoritma (model prosedural), atau scanner 3D. Pada zaman modern seperti sekarang model $3 D$ exploded view dapat diaplikasikan pada berbagai bidang keilmuan. Contohnya pada bidang medis, untuk menggambarkan rincian organ manusia, industri film digunakan untuk karakter dan animasi, pada industri game digunakan untuk aset atau karakter tokoh game, dan sejumlah penggunaan lainnya. Pembuatan model 3D dapat dilakukan menggunakan program khusus seperti 3DS Max, Maya, Blender bahkan masih banyak lagi lainnya. Bahkan tidak jarang model 3D di export dari software ke software yang lain untuk ditambahkan proses yang kemudian baru dapat digunakan sesuai kebutuhan pengguna teknologi (Jayanth, Kolati, Rajkumar, \& Patil, 2020).

Pada pengelompokanya sebenarnya model 3D tersebut dapat dibagi minimal menjadi dua kategori, yaitu (1) Solid, model solid ini mewakili volumetrik objek benda yang sedang dibuat. Model tersebut umumnya lebih tampak nyata atau realistis, tetapi memang secara teknis lebih rumit untuk dibuat. Model solid banyak digunakan pada simulasi seperti keperluan medis dan simulasi teknik. (2) Shell, model shell ini menampakkan permukaan benda sedang dibuat, contohnya ukuran dimensional permukaan bidang. Model ini lebih mudah dibuat daripada model solid. Hampir semua model yang digunakan pada game dan film tergolong pada 
model shell (Deepika, Gokulraj, Srisharaan, \& Sashang, 2020).

Secara garis besar $3 D$ Exploded View merupakan bentuk diagram, gambar teknis atau skematis yang menunjukkan hubungan berbentuk next-preview atau urutan perakitan berbagai komponen dari suatu objek benda umumnya berbentuk 2D maupun 3D. Pada exploded view display komponen dari suatu objek akan dipisahkan oleh jarak dalam diagram tiga dimensi. Selanjutnya sesuai dengan kebutuhan, objek yang dimaksud dapat ditampilkan lagi sehingga seolah-olah terdapat perubahan yang terjadi pada titik pusat objek. Hal tersebut yang menyebabkan bagian atau subobjek dapat terpisah dengan jarak tertentu dari posisi awalnya. Model animasi dan gambar exploded view biasanya digunakan pada part katalog komponen permesinan, manual book, petunjuk perakitan dan pembongkaran, dan buku instruksional sejenisnya (Tasneem, Johnston, \& Ophoff, 2019).

Proyeksi gambar exploded view biasanya diposisikan dari sisi bagian atas maupun menyilang dari sisi kanan bahkan juga bisa dari sisi kiri objek. Objek yang biasanya dipergunakan sebagai model exploded view adalah jenis objek yang menunjukkan proses perakitan yang diinginkan dari suatu komponen mekanis. Exploded view mampu menunjukkan semua komponen secara lengkap dapat dirakit secara presisi sesuai dengan urutan pemasangan (Sergey, Zhdanov, Chebotarev, \& Rabinovich, 2015).

Dalam sistem mekanis biasanya komponen yang paling dekat dengan pusat atau yang merupakan bagian utama dirakit terlebih dahulu. Objek ini juga dapat menggambarkan dengan jelas proses pembongkaran bagian komponen atau part mulai dari awal hingga akhir perakitan maupun pembongkaran. Membahas tentang kesesuaian dan kevalidan media terhadap kurikulum dinilai telah sesuai. Minimal sebuah pengembangan media memenuhi dua macam validitas. Seperti telah ditunjukan dengan tahapan validasi ahli terhadap isi materi maupun validasi terhadap konstruksi media (Suharsimi, 2013). Sehingga dari keunggulan tersebut exploded view sangat cocok digunakan untuk media belajar khususnya topik belajar yang mensyaratkan prosedur urutan tindakan. Sehingga dinilai sangat cocok untuk media belajar praktikum salah satunya adalah mata kuliah PPTOUM6039 Sistem Kontrol sasis dan pemindah tenaga, $2 \mathrm{SKS} / 4 \mathrm{JS}$ di program studi S1 pendidikan Teknik Otomotif.

Berdasarkan hasil output analisis data dapat disimpulkan bahwa terdapat perbedaan yang signifikan capaian prestasi kognitif penggunaan media oleh para mahasiswa. Hal tersebut relevan terhadap konsep media sebagai produk yang dapat dimanfaatkan untuk mendorong pemahaman konsep utamanya aspek kognitif. Pada aspek motivasi belajar juga telah tampak jelas dengan memanfaatkan produk pada kelas praktik, mahasiswa lebih termotivasi untuk mencoba menggunakan media. Secara sekilas memang menarik dan mengandung konten yang relevan. Media yang dimanfaatkan tersebut tentunya secara otomatis menciptakan pengalaman bagi pengguna serta secara langsung memberikan nilai kebermanfaatan bagi mahasiswa dalam mengikuti proses pembelajaran (Kusnawa, 2012).

Faktor yang mempengaruhi perkembangan kognitif pada subjek atau tingkat mahasiswa tentunya ada beberapa poin yang berperan. Mengenai faktor yang mempengaruhi perkembangan kognitif individu dapat terjadi minimal dua faktor utama. (1) faktor hereditas, potensi ini memiliki pada dasarnya berkembang sejak manusia lahir. Dapat diartikan potensi ini merupakan potensi yang berkembang secara alami serta akan lebih optimal jika didukung dengan peran lingkungan yang baik. (2) faktor lingkungan, pada aspek ini kontribusi lingkungan terhadap perkembangan kognitif sangat besar yaitu lingkungan informal contohnya keluarga dan formal contohnya lembaga pendidikan.

Pada konsep ini jelas bahwa peran pendidikan memiliki pengaruh yang besar pada perkembangan kognitif. Perbandingan perkembangan kognitif secara individual tampak pada kemampuan dan kecepatan belajar yang tercermin dari misalnya kemampuan, keterampilan, maupun sikap dan kebiasaan belajar hingga sampai pada kualitas proses serta hasil belajar. Perbedaan individu ini akan sangat tampak pada aktivitas pembelajaran kelas, utamanya pada kelas praktik yang menitikberatkan terhadap kemampuan kognitif dalam menunjang aktivitas unjuk kerja yang sering disebut kompetensi (Asrori, 2013). Hasil penelitian pengembangan media ini secara umum relevan untuk mengakselerasi proses serta pencapaian tujuan belajar. Penelitian ini juga sejalan terhadap hasil penelitian sejenis. Misalnya pemanfaatan e-book ataupun e-modul 
256 JINOTEP (Jurnal Inovasi dan Teknologi Pembelajaran) Kajian dan Riset dalam Teknologi Pembelajaran Vol.8, No.3, November 2021, Hal. 247-257

yang ternyata juga memberikan kontribusi hasil yang efektif bagi proses pembelajaran kelas praktikum (Ramadhan, Jalinus, Ta'ali, \& Mulianti, 2021).

\section{SIMPULAN}

Relevan dan didasarkan terhadap hasil analisis pengembangan produk media $3 D$ Exploded View disimpulkan bahwa secara umum produk median ini telah valid secara konten dan layak digunakan untuk ruang lingkup terbatas. Hal tersebut berdasar pada putusan dari ahli media sebagai validator ahli. Selanjutnya pada aspek pengaruh terhadap peningkatan kebermaknaan belajar menunjukan skor rerata 86,8 dengan makna sangat baik. Pada aspek peningkatan motivasi belajar mahasiswa menunjukan skor rerata 87,6 dengan makna sangat baik. Pada aspek peningkatan prestasi kognitif mahasiswa menunjukan skor rerata 78,8 dengan makna baik diatas standar capaian lulusan (SCPL). Sedangkan ditinjau dari aspek efektifitas, pemanfaatan media telah menunjukkan nilai $72 \%$ lebih efektif, dibuktikan dengan indikator periode penyampaian materi yang lebih singkat serta mampu memberikan manfaat bagi dosen dan mahasiswa dalam melaksanakan proses pembelajaran praktik, paling utama terletak pada proses pembelajaran asynchronous learning.

Media $3 D$ Exploded View dinilai relevan untuk diterapkan pada pembelajaran praktik yang memiliki ciri membutuhkan pemahaman urutan atau pedoman perakitan maupun pembongkaran sebuah alat atau mesin. Media ini layak direkomendasikan untuk dimanfaatkan dalam sebuah pembelajaran. Bagi peneliti lanjutan, media $3 D$ Exploded View dapat dikembangkan sekaligus dilakukan kajian tindak lanjut terutama jika diterapkan pada bidang pembelajaran yang sejenis.

\section{UCAPAN TERIMA KASIH}

Penelitian inovasi belajar pada bidang pengembangan media $3 D$ Exploded View merupakan wujud kontribusi dan upaya pengembangan pembelajaran pada tingkat program studi melalui pembiayaan penelitian PNBP Universitas Negeri Malang. Ucapan terimakasih kepada LP3 dan LP2M UM yang telah membuka skema penelitian yang spesifik berfokus pada bidang inovasi pembelajaran tingkat universitas. Ucapan terimakasih kepada tim pengembang dan seluruh mahasiswa yang ikut terlibat khususnya S1 Program Studi Teknik Otomotif.

\section{DAFTAR RUJUKAN}

Anwar. (2012). Pendidikan Kecakapan Hidup. Bandung: Alfabeta.

Asrori, M. (2013). Psikologi Pembelajaran. Bandung: Wacana Prima.

Azwar, S. (2014). Tes Prestasi Fungsi dan Pengembangan Pengukuran Prestasi Belajar. Yogyakarta: Pustaka Pelajar.

Basuki I, H. (2014). Asesmen Pembelajaran. Bandung: Remaja Rosdakarya.

Chen, X., Ma, H., Wan, J., Li, B., \& Xia, T. (2017). Multi-view 3D object detection network for autonomous driving. Conference on Computer Vision and Pattern Recognition. 20, hal. 65266534.

IEEE. doi:https://doi.org/10.1109/CVPR.2017.691

Choy, C. B., Xu, D., Gwak, J., Chen, K., \& Savarese, S. (2016). 3D-R2N2: A unified approach for single and multi-view 3D objects. Journal Computer Science, 9912, 628-644. doi:https://doi.org/10.1007/978-3-319-46484$8 \_38$

Costa, C. M., Veiga, G., Sousa, A., Rocha, L., Oliveira, E., Cardoso, H. L., \& Thomas, U. (2018). Automatic Generation of Disassembly Sequences and Exploded Views from SolidWorks Symbolic Geometric Relationships. International Conference on Autonomous Robot Systems and Competitions. Torres Vedras, Portugal: IEEE. doi:10.1109/ICARSC.2018.8374185

Deepika, J., Gokulraj, J., Srisharaan, S., \& Sashang, S. (2020). Enhanced Technique of Augmented Reality and Virtual Reality with Brain Computer Interface in Education. International Journal of Advanced Science and Technology, 29(7), $12185-12190$.

Ipate, G., Ilie, F., \& C, A. C. (2020). Finite element 3D numerical simulation study of car braking systems and brake disc/drum - pad/shoe friction couple materials. materials. International Conference on Thermal Equipments, Renewable Energy and Rural Development, 180, hal. 1-6. doi:https://doi.org/10.1051/e3sconf/202018003 003

Jayanth, A. Y., Kolati, N. S., Rajkumar, R., \& Patil, D. S. (2020). Virtual Reality Emulation Platform for Image Visualization. International Journal of Advanced Science and Technology, 19(7), 8266-8272.

Karisman, A., Wulandari, F., \& Adipraja, R. (2019). Aplikasi Media Pembelajaran Augmented Reality Pada Perangkat Keras Komputer Berbasis Android. Jurnal Teknik Informatika dan Sistem Informasi, 6(1), 18-30. 
Kusnawa, W. S. (2012). Taksonomi Kognitif (Perkembangan Ragam Berpikir). Bandung: Remaja Rosdakarya.

Mayilyan, H. (2019). Augmented Reality in Education, AR Globe Project Assessment in Actual Teaching-Learning Environment. International Journal of Learning, Teaching and Educational Research, 18(3), 1-14. doi:https://doi.org/10.26803/ijlter.18.3.1

Nisaun, M., Subiyanto, S., \& Murnomo, A. (2020). The Effectiveness of Augmented Reality App to Improve Students Achievement in Learning Introduction to Animals. Journal of Education and Learning, 12(4), 1-10. doi:http://dx.doi.org/10.11591/edulearn.v12i4.9 334

Pangestu, D. A., Fitri, I., \& Fauziah. (2020). Augmented Reality Sebagai Media Pengenalan dan Promosi Universitas Nasional. Jurnal Teknologi Informasi, 4(1).

Ramadhan, A. A., Jalinus, N., Ta'ali, \& Mulianti. (2021). Pengembangan Modul Elektronik Berbasis Model Pembelajaran Self Directed Learning Pada Mata Pelajaran Pengelasan. JINOTEP (Jurnal Inovasi Teknologi Pembelajaran), $\quad 8(1), \quad$ 91-100. doi:10.17977/um031v8i12021p091

Saifuddin, A. (2016). Konstruksi Tes Kemampuan Kognitif. Yogyakarta: Pustaka Pelajar.

Sergey, S., Zhdanov, F., Chebotarev, P., \& Rabinovich, P. (2015). Interactive Educational Content Based on Augmented Reality and 3D Visualization. International Young Scientists Conference on Computational Science. 66, hal. 720-729. Procedia Computer Science. doi:https://doi.org/10.1016/j.procs.2015.11.082

Sonhadji, A. (2013). Manusia,Teknologi dan Pendidikan (Menuju Peradaban Baru). Malang: UM Press.

Suhana, C. (2014). Konsep Strategi Pembelajaran. Bandung: Refika Aditama.
Suharsimi, A. (2013). Dasar-Dasar Evaluasi Pendidikan. Jakarta: Bumi Aksara.

Sukmadinata, N. S. (2013). Pengembangan Kurikulum (Teori dan Praktek). Bandung: Remaja Rosdakarya.

Tasneem, K., Johnston, K., \& Ophoff, J. (2019). The Impact of an Augmented Reality Application on Learning Motivation of Students. Journal Advances in Human-Computer Interaction, 4556. doi:https://doi.org/10.1155/2019/7208494

Tasrif, E., Mubai, A., Huda, A., \& Rukun, K. (2020). Pemanfaatan media pembelajaran berbasis augmented reality menggunakan aplikasi Ar Jarkom pada mata kuliah instalasi jaringan komputer. Jurnal Konseling dan Pendidikan, 8(3). doi:https://doi.org/10.29210/153400

Tymrak, B., Kreiger, M., \& J.M.Pearce. (2014). Mechanical properties of components fabricated with open-source 3-D printers under realistic environmental conditions. Journal Materials and Design, 58, 242-246. doi:https://doi.org/10.1016/j.matdes.2014.02.03 8

Weng, Z., Wanga, J., T.Senthil, \& Wu, L. (2016). Mechanical and thermal properties of $\mathrm{ABS} /$ montmorillonite nanocomposites for fused deposition modeling 3D printing. Journal Materials and Design, 102, 276-283. doi:https://doi.org/10.1016/j.matdes.2016.04.04 5

Widayaningsih, N. H., \& Handriyotopo. (2020). Perancangan Augmented Reality Berbasis Android Sebagai Promosi Taman Sriwedari Surakarta. Journal of Advertising and Visual Communication, 1(2), 1-22. doi:https://doi.org/10.33153/citrawira.v1i2.329 8

Wilmot, L., Agrawala, M., Curless, B., \& Salesin, D. (2018). Automated Generation of Interactive 3D Exploded View Diagrams. ACM Transactions on Graphics, 27(3), 1-7. doi:https://doi.org/10.1145/1360612.1360700 